\title{
Fishes community composition and patterns of species distribution in Neotropical streams
}

\author{
Laísa Wociechoski Cavalheiro ${ }^{I} \mathbb{B}_{0}$ \& Clarice Bernhardt Fialho ${ }^{I}$ \\ ${ }^{1}$ Universidade Federal do Rio Grande do Sul, Departamento de Zoologia, Programa de Pós-Graduação em \\ Biologia Animal, Avenida Bento Gonçalves 9500, Prédio 43435, CEP 91501-970, Porto Alegre, RS, Brasil \\ *Corresponding author: Laísa WociechoskiCavalheiro, e-mail: isa_woci@hotmail.com
}

CAVALHEIRO, L.W., FIALHO, C.B. Fishes community composition and patterns of species distribution in Neotropical streams. Biota Neotropica. 20(1): e20190828. http://dx.doi.org/10.1590/1676-0611-BN-2019-0828

Abstract: The ichthyofauna of streams in the Neotropical region is not yet fully known. This study aims to investigate the ichthyofauna composition of six streams of the Ijuí River sub-basin, Rio Grande do Sul State, inserted in the Uruguay River basin, as to contribute to the knowledge of fishes species richness and distribution in the south of Brazil. Sampling was carried out between July 2015 and May 2016, bimonthly, using the technique of electric fishing to collect the fishes. Spatial variations (per sampled stream) in the ichthyofauna composition were tested with a permutational multivariate analysis of variance. In total, we collected 5,029 individuals from 55 species, 13 families and five orders. From these species, 17 are endemic to the Uruguay River basin. Five species alone represented approximately $70 \%$ of the ichthyofauna abundance sampled. Our hypothesis that the fish community composition is not homogeneous along the streams sampled was confirmed and we observed that species complexity increases from the upstream closest area to the downstream according to the river continuum concept.

Keywords: Abundance, Characidae, Heptapteridae, Loricariidae, Richness, Uruguay River basin.

\section{Composição da comunidade de peixes e padrões de distribuição de espécies em riachos Neotropiacais}

Resumo: A ictiofauna de riachos na região Neotropical ainda não é totalmente conhecida. Este estudo objetiva investigar a composição da ictiofauna de seis riachos da sub-bacia do rio Ijuí, estado do Rio Grande do Sul, inseridos na bacia do rio Uruguai, de forma a contribuir no conhecimento da riqueza e distribuição de espécies de peixes no sul do Brasil. A amostragem foi realizada entre julho de 2015 e maio de 2016, bimestralmente, utilizando a técnica da pesca elétrica. Variações espaciais (por riacho amostrado) na composição da ictiofauna foram testadas com uma análise de variância multivariada permutacional. No total, coletamos 5029 indivíduos de 55 espécies, 13 famílias e cinco ordens. Destas espécies, 17 são endêmicas da bacia do rio Uruguai. Cinco espécies sozinhas representaram aproximadamente $70 \%$ da abundância da ictiofauna amostrada. Nossa hipótese de que a composição da comunidade de peixes não é homogênea ao longo dos riachos amostrados foi confirmada e observamos que a complexidade das espécies aumenta de áreas à montante em direção à jusante, conforme o conceito do rio contínuo. Palavras-chave: Abundância, bacia do rio Uruguai, Characidae, Heptapteridae, Loricariidae, Riqueza. 


\section{Introduction}

The ichthyofauna of the Neotropical region comprises 4,475 valid species, and perhaps more than 1,550 undescribed ones (Reis 2013). It is estimated that there are 6,025 species and that this number could be surpassed, overcoming the 8,000 species (Schaefer 1998, Reis 2013). In South America, this ichthyofauna occupies a variety of habitats, from large rivers to small and medium-sized streams, swamps, lagoons, high altitude lakes, among others (Vari \& Malabarba 1998, Reis 2013).

Among the habitats occupied by the ichthyofauna, streams are known as lotic environments, with unidirectional water flows from headwaters to mouth and may have non-persistent flooding areas during rainy seasons (Esteves \& Aranha 1999, Uieda \& Castro 1999). They are known to have a wide variety of mesohabitats due to environmental gradients ranging from rocky riffles and runs to sandy pools and backwaters, in addition to a variety of marginal vegetation in the stream bank (Araújo-Lima et al. 1995, Esteves \& Aranha 1999). In southern and southeastern Brazil, the streams may present high dissolved oxygen concentration and large seasonal temperature variation, with influence of drainage basin geomorphology under abiotic components as transparency, $\mathrm{pH}$ and conductivity (Araújo-Lima et al. 1995, Esteves \& Aranha 1999).

The streams have high biological diversity and great importance in maintaining the integrity of the entire ecosystem (Meyer et al. 2007). These environments frequently present isolated populations of fish, often undescribed, with a high degree of endemism (Langeani et al. 2007, Reis 2013, Vidotto-Magnoni et al. 2015). The assessment of species in these sites contributes, therefore, to the understanding of the distribution of the species already described and to the description of new taxa (Pereira et al. 2014). Studies of species distribution assist in estimating changes in habit susceptibility to anthropogenic impacts that influence the composition of aquatic communities and are useful in the definition of priority areas for conservation (Bailly et al. 2016, Rose et al. 2016).

Freshwater ecosystems are particularly vulnerable to anthropogenic impacts that often promote the proliferation of some populations in the face of the decline, or even the extinction of others (Agostinho et al. 1999, Bailly et al. 2016). In streams, the susceptibility to these impacts may be higher because of the reduced size of these habitats and the sensitivity of microhabitats (Galves et al. 2009, Bonato \& Fialho 2016). The fishes community is an indicator of the biological integrity of freshwater systems (Moore et al. 1997) and the knowledge of streams ichthyofauna is an informative tool to propose mitigation measures to these impacts (Vidotto-Magnoni et al. 2015). In the hydrographic region of River Uruguay, Brazil, anthropogenic impacts consist mainly on the environmental degradation in areas of high population and industrial density caused by agricultural activities, by the construction of hydroelectric dams, with the disappearance of lotic environments, and by the constant introduction of exotic species (Malabarba et al. 2009).

The Uruguay River is one of the main tributaries of the La Plata River basin which, in South America, comprehends the second largest drainage system, behind only the Amazonas (Cappato \& Yanosky 2009). The Uruguay River has an extension of 2,200 km (ANA 2016) with a drainage area of about $365,000 \mathrm{~km}^{2}$ (Di Persia \& Neiff 1986, Albert \& Reis 2011). Its main tributaries are the Negro River, Quaraí River, Ibicuí River and Ijuí River (Carvalho \& Reis 2009). The ichthyofauna of the
Uruguay River drainage system comprises about 275 species known; from these, 78 (28\%) are endemic (Bertaco et al. 2016).

The "river continuum concept" proposed by Vannote et al. (1980) explains the distribution pattern of fishes fauna following the upstreamdownstream gradient. This theory describes the structure and functions of communities along river systems, considering gradients of physical factors, formed by the drainage network, which include energy input, organic matter transport and use by macroinvertebrates functional feeding groups (Vannote et al. 1980). In addition, this concept proposes that community complexity increases from upstream to downstream, with the alteration on the composition of species and trophic guilds being influenced by continuum gradients (Vannote et al. 1980).

This study aims, therefore, to evaluate the composition of the fishes community and the pattern of species distribution in streams located along a longitudinal gradient (upstream-downstream) in the hydrographic sub-basin of the Ijuí River, tributary of Uruguay River, intending to contribute to the knowledge of the richness and abundance of species in this region of the south of Brazil. The hypothesis is that the composition of the fishes community is not homogeneous along the streams sampled, and that its complexity increases from the upstream closest area to the downstream (mouth of the Ijuí River sub-basin in the Uruguay River basin), according to the "river continuum concept".

\section{Material and Methods}

Collections were carried out in six streams, located in rural areas of the Ijuí River sub-basin, at the northwest region of the Rio Grande do Sul State, southern Brazil. With a drainage of $10,649.13 \mathrm{Km}^{2}$, it is located in the middle portion of the Uruguay River hydrographic network (FEPAM 2016) (Figure 1). In order to sample different portions of the Ijuí River sub-basin (high, middle and low), chosen streams were distributed along the longitudinal gradient, from upstream to downstream areas, near the mouth of the Ijuí River sub-basin in the Uruguay River (Figure 1). From the sampled streams, two are locate in an upper portion of the sub-basin: stream $1\left(28^{\circ} 18^{\prime} 58.4^{\prime \prime} \mathrm{S}, 53^{\circ} 54^{\prime} 17.9^{\prime} \mathrm{W}\right)$ (Figure 2a) and stream $2\left(28^{\circ} 25^{\prime} 56.2^{\prime \prime} \mathrm{S}, 53^{\circ} 58^{\prime} 14.9^{\prime \prime} \mathrm{W}\right)$ (Figure 2b); two are in the mid portion: stream $3\left(28^{\circ} 12^{\prime} 06.2^{\prime \prime} \mathrm{S}, 54^{\circ} 13^{\prime} 06.9^{\prime \prime} \mathrm{W}\right)$ (Figure 2c) and stream $4\left(28^{\circ} 23^{\prime} 41.5^{\prime}\right.$ 'S, 54 $\left.4^{\circ} 7^{\prime} 05.9^{\prime \prime} \mathrm{W}\right)$ (Figure 2d); and two are in the lower portion: stream $5\left(28^{\circ} 13^{\prime} 40.8^{\prime}\right.$ 'S, 54 $\left.57^{\prime} 24.8^{\prime \prime} \mathrm{W}\right)$

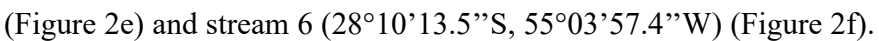
Anthropogenic activities developed nearby the streams consist mainly in agriculture (soybean crops) and cattle farming, with swine farming in the corresponding area to the stream 4 . The riparian vegetation, next to the streams, is poorly preserved at all sampling sites, corresponding to narrow tree lines running along the streams, often less than $5 \mathrm{~m}$ width.

Biological samples were collected bimonthly, from July 2015 to May 2016, summing up six capture expeditions for each stream (July, September, and November 2015, and January, March, and May 2016). Fishes were collected using the electric fishing technique, in an extension of $100 \mathrm{~m}$ in each stream, for the period of an hour. Fieldwork and sampling were carried out under a scientific collection permit (Permit Number 48291-1) issued by the Instituto Chico Mendes de Conservação da Biodiversidade, Ministério do Meio Ambiente, Brasília - Distrito Federal, Brazil. This study was conducted in accordance with protocols approved in their ethical and methodological aspects, for the 


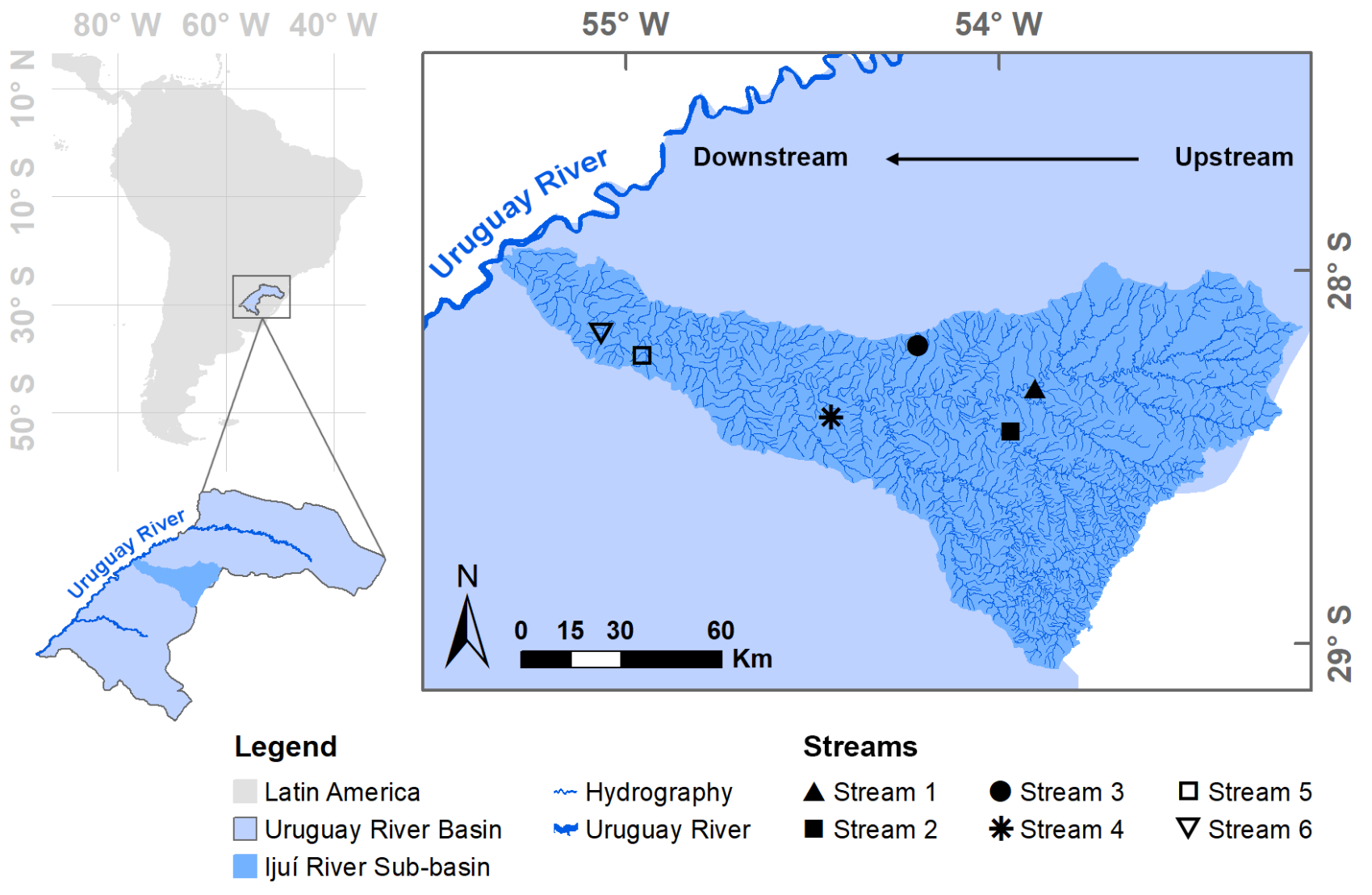

Figure 1. Location of the sampled streams in the Ijuí River sub-basin and its respective position into the Uruguay River hydrographic basin, Brazil.

use of fish, by the Ethics Committee on Animal Use of the Universidade Federal do Rio Grande do Sul, Brazil (Permit Number 35495).

In the field, individuals were anesthetized and euthanized with eugenol $10 \%$ (Jenkins et al. 2014) and fixed with formalin 10\%. In the laboratory, specimens were selected and identified before being preserved in alcohol $70 \%$. Species identification was made according to criteria of the literature (Buckup \& Hahn 2000, Casciotta et al. 2002, Lucena 2007, Ghazzi 2008, Carvalho \& Reis 2009, Malabarba et al. 2015) and specialists. The classification and nomenclature followed Eschmeyer et al. (2018) and Betancur-R et al. (2017) for Cichlidae. Voucher specimens were deposited in the ichthyologic collection of the Departamento de Zoologia, Universidade Federal do Rio Grande do Sul, Brazil. The fish community was described considering the abundance (number of individuals collected) and richness (number of species).

Spatial variations (for each sampled stream) on the ichthyofauna composition were tested using the permutational multivariate analysis of variance (PERMANOVA; $\alpha<0.05$ ), based on a dissimilarity matrix constructed with the Bray-Curtis index (Anderson 2001, Anderson et al. 2011, Borcard et al. 2011). Abundance data were standardized using $\log _{10}(y+1)$ (Legendre \& Legendre 1998, Anderson et al. 2011). The Bray-Curtis index was chosen as it considers the abundance data and enables the exclusion of joint absences (Anderson et al. 2011). This decision was made because we did not consider two samples to be more similar due to the sharing of absence of a particular species, since we do not have a priori information if the species does not actually exist in the local, or was simply not captured (Anderson et al. 2011). The pattern of species spatial distribution, if identified with the PERMANOVA, was visualized with a principal coordinates analysis (PoCA), using a dissimilarity matrix made with the Bray-Curtis index (Legendre \& Legendre 1998, Borcard et al. 2011). In the PCoA graph presenting the species composition along the sampled streams, only those species that contributed with a minimum of $10 \%$ of the explanation of the data distribution (eigenvectors $\geq \pm 0.10$ ) were shown, for the first two axis, in order to improve the visualization of distribution patters and avoid visual pollution. In the PCoA graph presenting the distribution of fish families, all species were shown. Statistical tests were carried out using R Project for Statistical Computing software, version 3.4.1. with the Vegan statistical package, version 2.4-5 (Oksanen et al. 2017).

\section{Results}

The ichthyofauna found in the six sampled streams in the Ijuí River basin is distributed within five orders, 13 families, 33 genera and 55 species, totalizing 5,029 individuals sampled (Table 1). The orders Characiformes and Siluriformes presented five families each, while Cichliformes, Gymnotiformes and Synbranchiformes were represented by a single family. The order Siluriformes was the most abundant in number of collected individuals (3,051 specimens), representing $60.68 \%$ of the total sampled, distributed within 17 genera. Characiformes presented the highest richness (23 species) and the second highest abundance ( $36.85 \%$ of individuals collected), comprised by 11 genera. Cichliformes had eight species and $1.25 \%$ of the total abundance, 
Cavalheiro, L.W. et al.
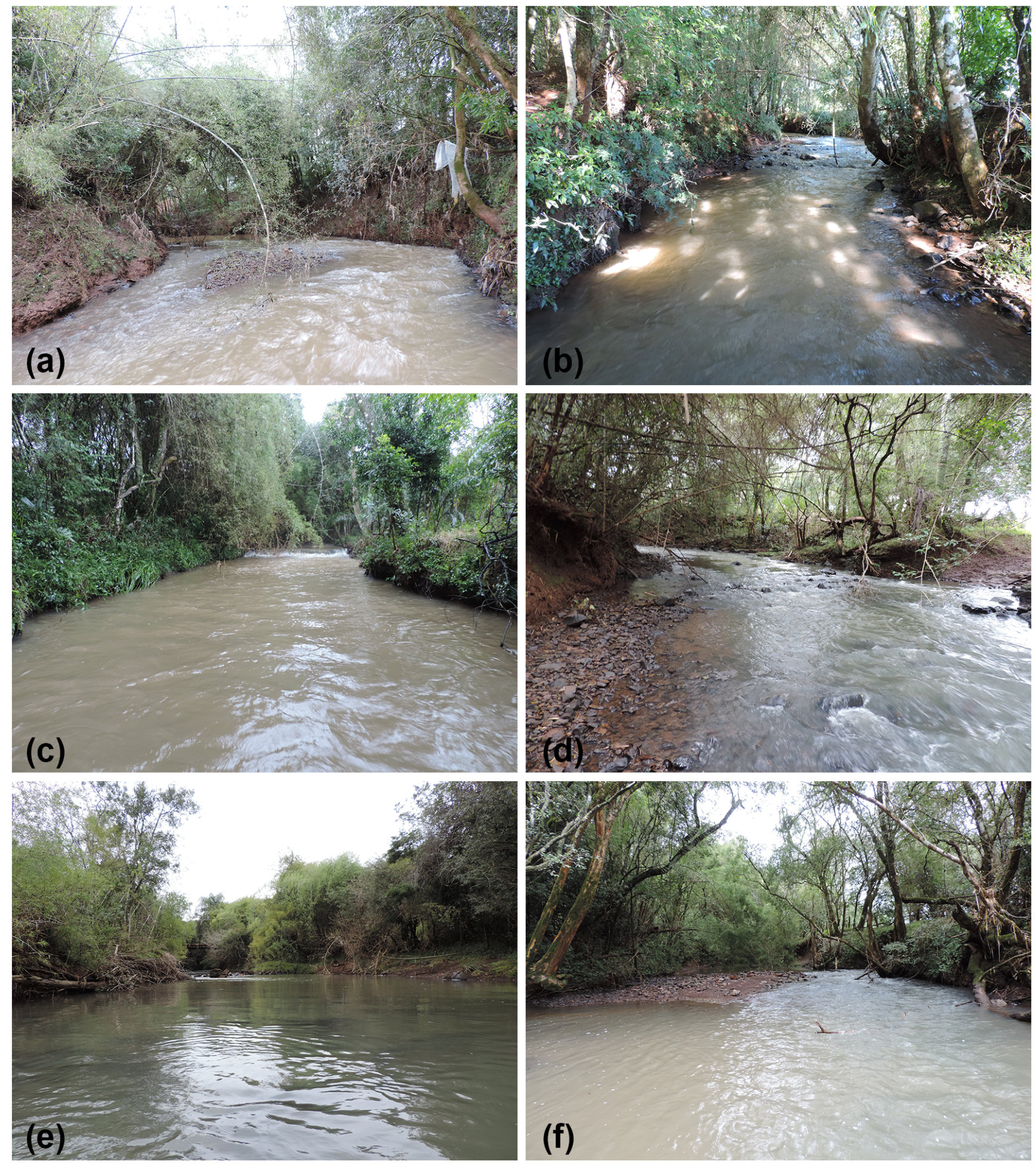

Figure 2. Sampling sites in the streams of the Ijuí River sub-basin, Brazil. Upper portion (upstream): (a) Stream 1 and (b) Stream 2; mid portion (midstream): (c) Stream 3 and (d) Stream 4; lower portion (downstream): (e) Stream 5 and (f) Stream 6. 


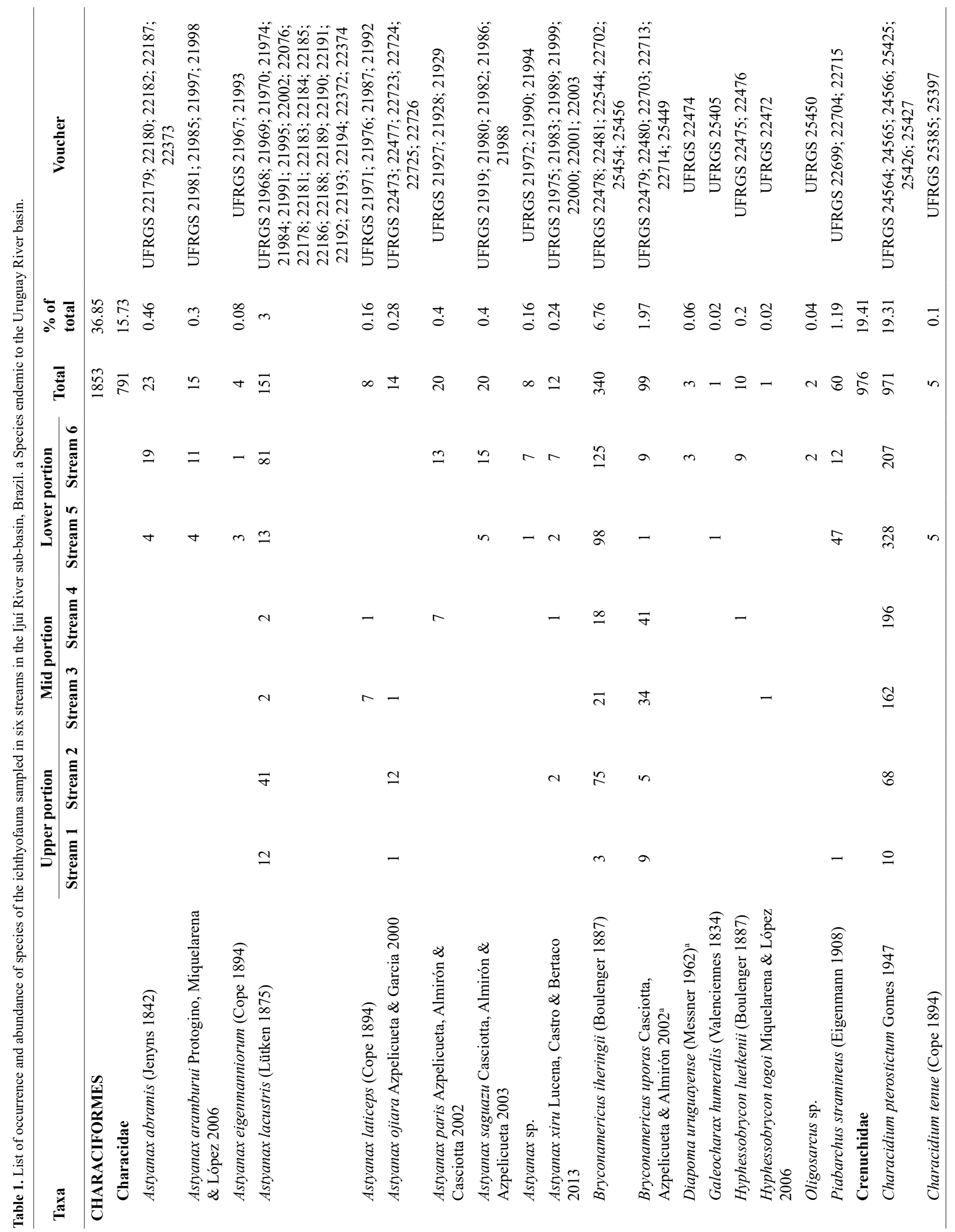


Cavalheiro, L.W. et al.

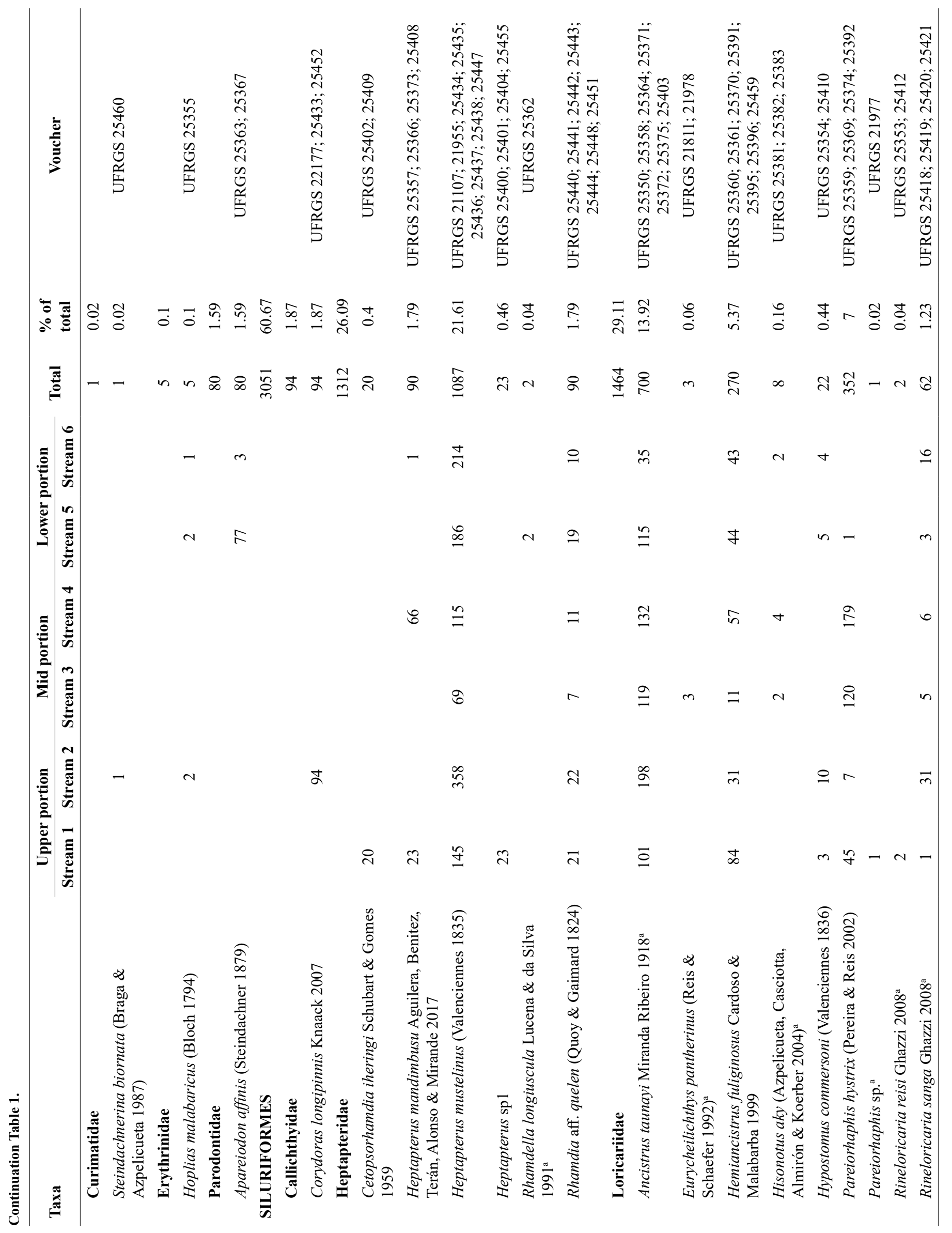




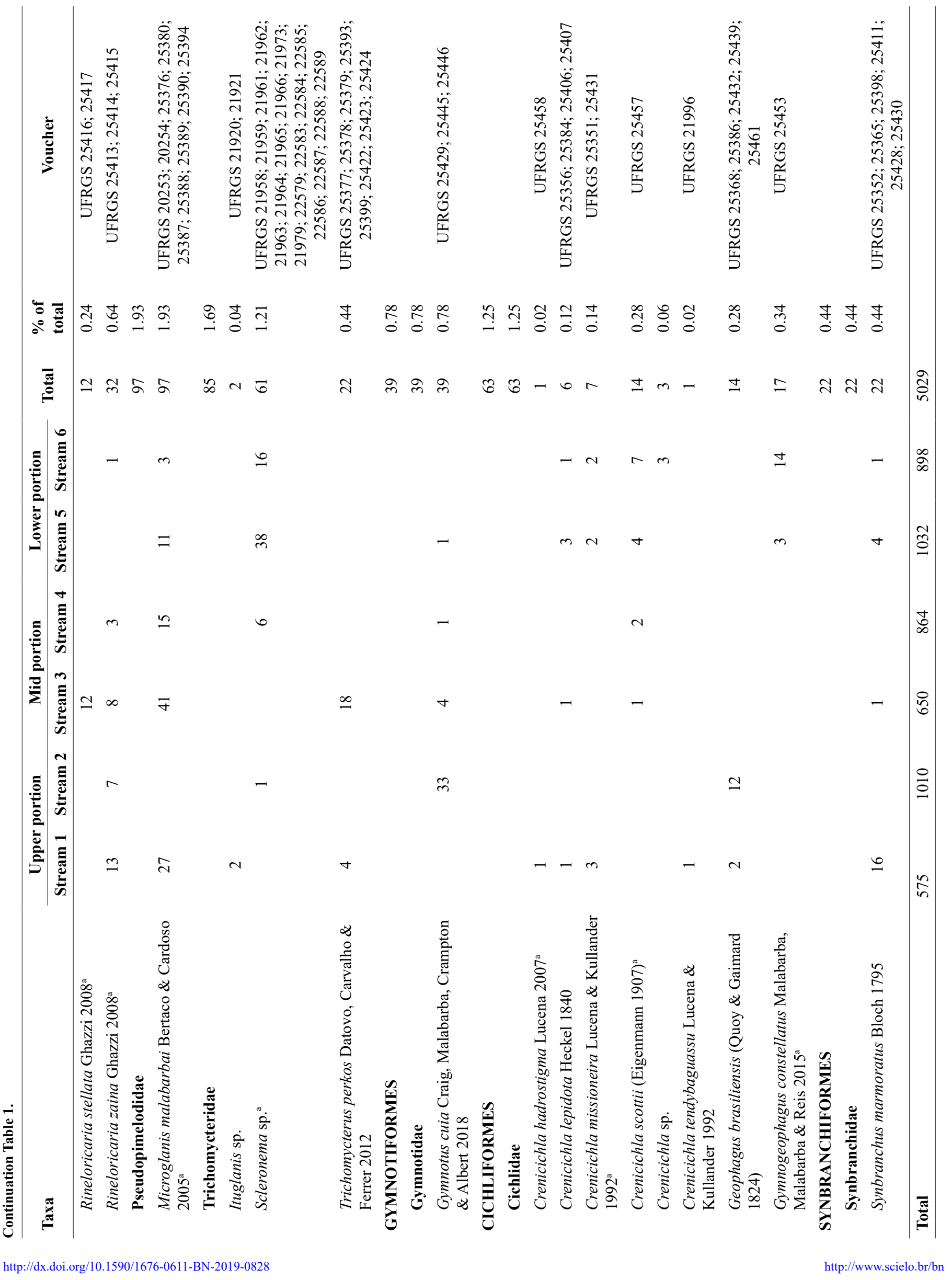


followed by Gymnotiformes and Synbranchiformes, with one species each, and $0.78 \%$ and $0.44 \%$ of the total number of collected specimens, respectively (Table 1). From the 55 fish species collected, 17 are endemic to the Uruguay River hydrographic basin and no exotic species were collected (Table 1).

Characidae had the highest number of species recorded, 18 , followed by Loricariidae, Cichlidae, Heptapteridae, and Trichomycteridae, with 11 , eight, six and three, respectively. In relation to the total of individuals captured, the most representative families were Loricariidae $(29.11 \%)$, Heptapteridae (26.09\%), Crenuchidae (19.41\%) and Characidae $(15.73 \%)$. The species with the highest number of individuals collected were Heptapterus mustelinus (Valenciennes 1835) (21.61\%), Characidium pterostictum Gomes 1947 (19.31\%), Ancistrus taunayi Miranda Ribeiro 1918 (13.92\%), Bryconamericus iheringii (Boulenger 1887) (7.00\%) and Pareiorhaphis hystrix (Pereira \& Reis 2002) (6.76\%), representing together approximately $70 \%$ of the ichthyofauna abundance. The abundance of the other species was inferior to $6 \%$ for each taxon (Table 1).

The distribution of species and the representativity of families were not homogenous throughout the altitudinal gradient of the Ijuí River sub-basin (Figure 3-4). A pattern of spatial variation on the ichthyofauna composition was detected, with differences in richness and species abundance from upstream (upper portion of the sub-basin) to downstream areas, near the mouth in the Uruguay River (sub-basin lower portion) according to PERMANOVA results (Df: 5, pseudo-F: $10.29, \mathrm{R}^{2}: 0.63$, p: 0.0001 ), which indicates that species distribution does not occur randomly. The streams were more similar to each other regarding the ichthyofauna composition, according to the geographical location along the sub-basin (upper, mid, and lower portion) (Figure 3). Species richness varied between sampled streams, detecting a higher number of species in the lower portion of the sub-basin: 34 in stream 6 and 31 in stream 5 . In the sub-basin mid portion, stream 3 and stream 4 presented 23 and 21 species, respectively, while in the upper portion were recorded 28 species in the stream 1 and 20 in the stream 2.

The most abundant species although appearing in all sampled sites, contributed to the segregation of the streams in the Principal Coordinates Analysis (Table 2; Figure 3). Ancistrus taunayi and $H$. mustelinus were associated with the upper portion of the sub-basin (streams 1 and 2), P. hystrix was associated to the mid portion (streams 3 and 4 ), while $B$. iheringii and $C$. pterostictum were linked to the stream in the lower areas (streams 5 and 6). Less abundant species also contributed to this segregation, the most important being, according to the PCoA eigenvectors (Table 2): Corydoras longipinnis Knaack 2007, Callichthyidae family, recorded only in the upper portion of the sub-basin, with 92 individuals collected in the stream 2, and Gymnotus cuia Craig, Malabarba, Crampton \& Albert 2018, with approximately $85 \%$ of the individuals collected in this same location; Bryconamericus uporas Casciotta, Azpelicueta \& Almirón, 2002 and Microglanis malabarbai Bertaco \& Cardoso, 2005, with $76 \%$ and 58\%, respectively, of individuals collected in the mid portion of the sub-basin (streams 3 and 4); and Scleronema sp., with $89 \%$ of the specimens collected in the lower portion (stream 5) (Figure 3).

A pattern in the representativity, abundance, and number of species and families in Characiformes, Siluriformes and Cichliformes is observed in relation to the second axis of PCoA (Figure 4). Siluriformes richness was higher in the upper portion of the Ijuí River sub-basin (streams 1 and 2), with 18 out of 22 collected species occurring in the area, from which six have been exclusive to it (considering only this study data). Stream 1 (upper portion) presented the highest richness of Siluriformes (16 species) and the highest number of this order taxa with exclusive occurrence, namely: Cetopsorhamdia iheringi Schubart \& Gomes 1959; Pareiorhaphis sp.; Rineloricaria reisi Ghazzi 2008; Ituglanis sp.; and Heptapteridae (identified only at family level). Siluriformes richness declined along the sub-basin, with 14 species recorded in the mid portion (streams 3 and 4) and 13 in the lower portion (streams 5 and 6) of Ijuí River (Figure 4).

The highest representativity of the Characiformes order occurred within the Characidae family, in the lower portion of the sub-basin (streams 5 and 6). Of the 18 species captured, 15 occurred in this area and eight were recorded exclusively for these two sampled streams (data from this study only). Likewise, the Cichliformes of the Cichlidae family are associated with the lower portion of the sub-basin, where their greatest abundance appeared (streams 5 and 6) (Figure 4).

\section{Discussion}

The species richness found in the streams of the Ijuí River sub-basin follows the pattern of freshwater fishes in the Neotropical region, with Characiformes and Siluriformes as the richest orders in number of species (Lowe-McConnell 1999, Malabarba \& Malabarba 2014). Our hypothesis that the fish community composition is not homogeneous along the streams sampled was confirmed and we observed that species complexity increases from the upstream closest area to the downstream according to the river continuum concept. The latitudinal variation of the richness within the Ijuí River sub-basin, smaller in the upstream streams (closer to the headwaters of the sub-basin), increasing towards the mouth in Uruguay River (streams 5 and 6), is an expected pattern, according to the "river continuum concept" proposed by Vannote et al. (1980). Although, upstream and midstream areas present virtually the same (or higher) number of species, the richness has increased considerably towards the streams located in the lower portion of the basin (downstream) and we believe this is due to the influence of the Uruguay River, located very close to streams 5 and 6 . According to the river continuum concept, the complexity of community structure and function increases along a river system as the increases of the complexity of the physical gradients dynamics formed by a drainage network (Vannote et al. 1980). Furthermore, the three streams with the smallest longitude (streams 1, 3 and 6) in relation to the correspondent streams (streams 2, 4 and 5), which occupy the same portion in the sub-basin (upper, mid, and lower) presented a higher number of species, respectively.

The knowledge about the influence of the global longitudinal gradient on the distribution of species richness is well established and, for freshwater fishes, remains the same even in anthropomorphized habitats, such as in large spatial reservoirs, although this distribution is better explained by the overlapping of factors, rather than a single hypothesis (Brown 2014, Bailly et al. 2016). For freshwater fishes, the species richness tends to decrease within the latitude and increase along the longitudinal fluvial gradients (Osborne \& Lewis 1992, Ibañez et al. 2009, Bailly et al. 2016) (same pattern found in our samplings). The further away from the headwaters, within a hydrographic basin, the greater the species richness, as new species are added downstream more easily 
Fishes composition in streams

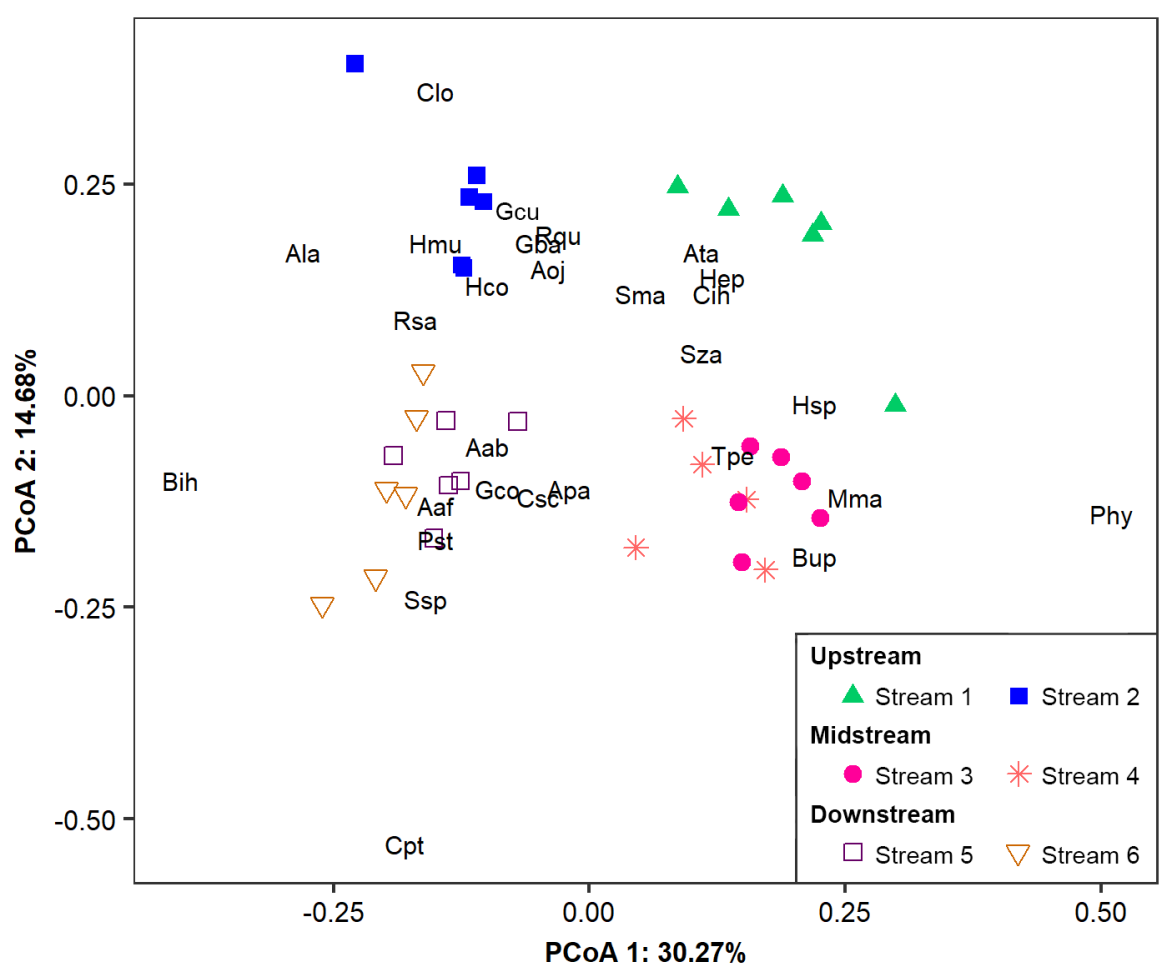

Figure 3. Principal Coordinates Analysis ( $\mathrm{PCoA}$ ) of the composition of species sampled in the upper (streams 1 and 2), mid (streams 3 and 4), and lower portion (streams 5 and 6) of the Ijuí River sub-basin, Brazil. Abbreviations list of species is in Table 2.

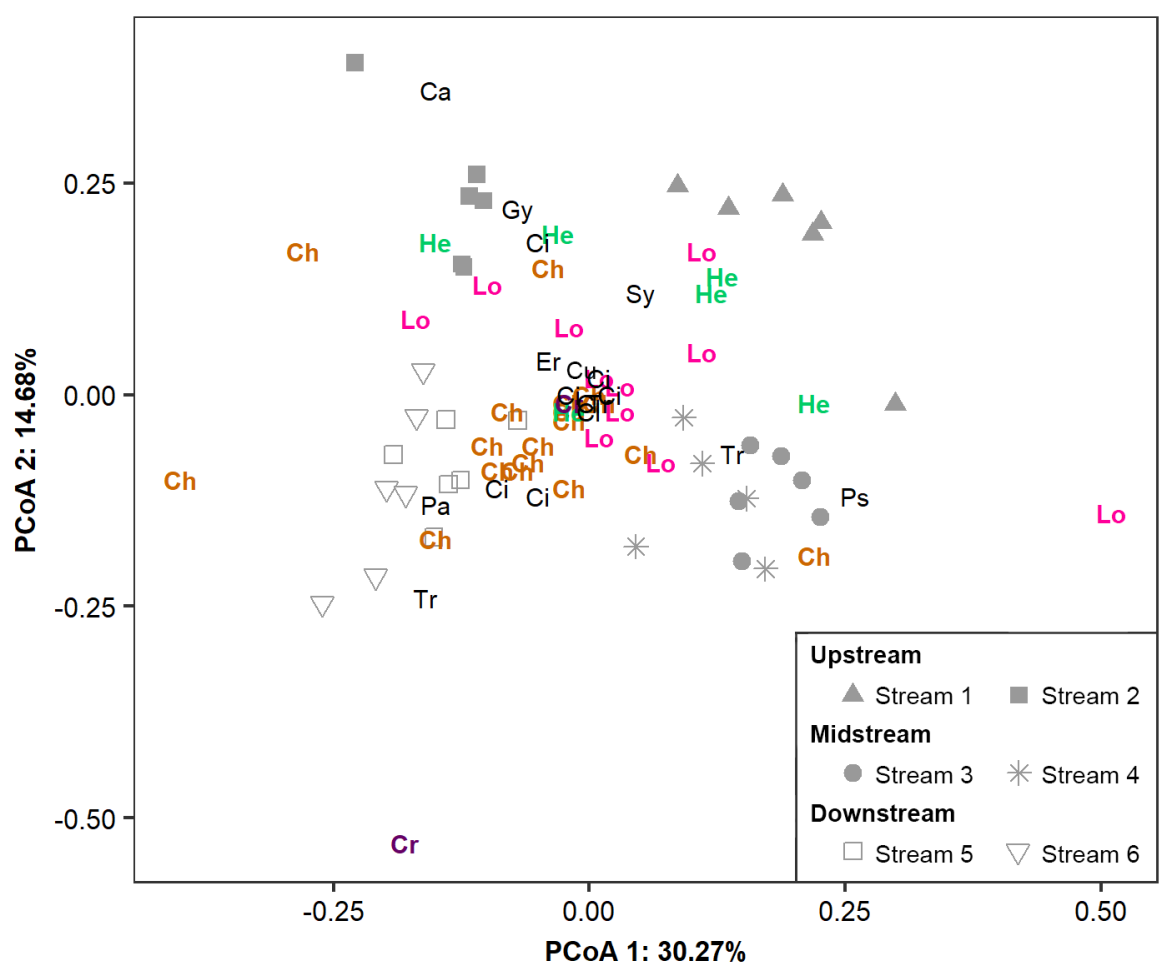

Figure 4. Principal Coordinates Analysis (PCoA) of the composition of species, indicating the representativeness of families, sampled in the upper (streams 1 and 2), mid (streams 3 and 4), and lower portion (streams 5 and 6) of the Ijuí River sub-basin, Brazil. The four most abundant are highlighted by bold typing: $\mathrm{Ch}$ : Characidae; $\mathrm{Cr}$ : Crenuchidae; $\mathrm{Cu}$ : Curimatidae; Er: Erythrinidae; Pa: Parodontidae; Ca: Callichthyidae; He: Heptapteridae; Lo: Loricariidae; Ps: Pseudopimelodidae; Tr: Trichomycteridae; Gy: Gymnotidae; Ci: Cichlidae; Sy: Synbranchidae. 
Cavalheiro, L.W. et al.

Table 2. Eigenvalues and eigenvectors from the Principal Coordinates Analysis (PCoA) of the composition of species sampled in six streams of the Ijuí River sub-basin, Brazil.

\begin{tabular}{lcc}
\hline & PCoA 1 & PCoA 2 \\
\hline Eigenvalue & 1.31 & 0.63 \\
Proportion Explained & 30.27 & 14.68 \\
Cumulative Proportion & 30.27 & 44.95 \\
\hline Taxa & Abbreviation & PCoA 1
\end{tabular}

\section{CHARACIFORMES}

\section{Characidae}

Astyanax abramis (Jenyns 1842)

Astyanax aramburui Protogino, Miquelarena \& López 2006

Astyanax eigenmanniorum (Cope 1894)

Astyanax lacustris (Lütken 1875)

Astyanax laticeps (Cope 1894)

Astyanax ojiara Azpelicueta \& Garcia 2000

Astyanax paris Azpelicueta, Almirón \& Casciotta 2002

Astyanax saguazu Casciotta, Almirón \& Azpelicueta 2003

Astyanax sp.

Astyanax xiru Lucena, Castro \& Bertaco 2013

Bryconamericus iheringii (Boulenger 1887)

Bryconamericus uporas Casciotta, Azpelicueta \& Almirón 2002

Diapoma uruguayense (Messner 1962)

Galeocharax humeralis (Valenciennes 1834)

Hyphessobrycon luetkenii (Boulenger 1887)

Hyphessobrycon togoi Miquelarena \& López 2006

Oligosarcus sp.

Piabarchus stramineus (Eigenmann 1908)

\section{Crenuchidae}

Characidium pterostictum Gomes 1947

Characidium tenue (Cope 1894)

Curimatidae

Steindachnerina biornata (Braga \& Azpelicueta 1987)

\section{Erythrinidae}

Hoplias malabaricus (Bloch 1794)

Parodontidae

Apareiodon affinis (Steindachner 1879)

\section{SILURIFORMES}

\section{Callichthyidae}

Corydoras longipinnis Knaack 2007

\section{Heptapteridae}

Cetopsorhamdia iheringi Schubart \& Gomes 1959

Heptapterus mandimbusu Aguilera, Benitez, Terán, Alonso \& Mirande 2017

Heptapterus mustelinus (Valenciennes 1835)

Heptapterus sp1

\begin{tabular}{|c|c|c|}
\hline $\mathrm{Aab}$ & -0.10 & -0.06 \\
\hline Aar & -0.07 & -0.09 \\
\hline Aei & -0.02 & -0.02 \\
\hline Ala & -0.28 & 0.17 \\
\hline Alat & 0.05 & -0.07 \\
\hline Aoj & -0.04 & 0.15 \\
\hline Apa & -0.02 & -0.11 \\
\hline Asa & -0.09 & -0.09 \\
\hline Asp & -0.05 & -0.06 \\
\hline Axi & -0.08 & -0.02 \\
\hline Bih & -0.40 & -0.10 \\
\hline Bup & 0.22 & -0.19 \\
\hline Dur & -0.02 & -0.03 \\
\hline Gum & 0.00 & 0.00 \\
\hline Hyl & -0.06 & -0.08 \\
\hline Hto & 0.01 & -0.01 \\
\hline Osp & -0.02 & -0.01 \\
\hline Pst & -0.15 & -0.17 \\
\hline $\mathrm{Cpt}$ & -0.18 & -0.53 \\
\hline Cte & -0.02 & -0.01 \\
\hline Sbi & -0.01 & 0.03 \\
\hline Hom & -0.04 & 0.04 \\
\hline Aaf & -0.15 & -0.13 \\
\hline Clo & -0.15 & 0.36 \\
\hline Cih & 0.12 & 0.12 \\
\hline Hsp & 0.22 & -0.01 \\
\hline $\mathrm{Hmu}$ & -0.15 & 0.18 \\
\hline Hep & 0.13 & 0.14 \\
\hline
\end{tabular}


Continuation Table 2.

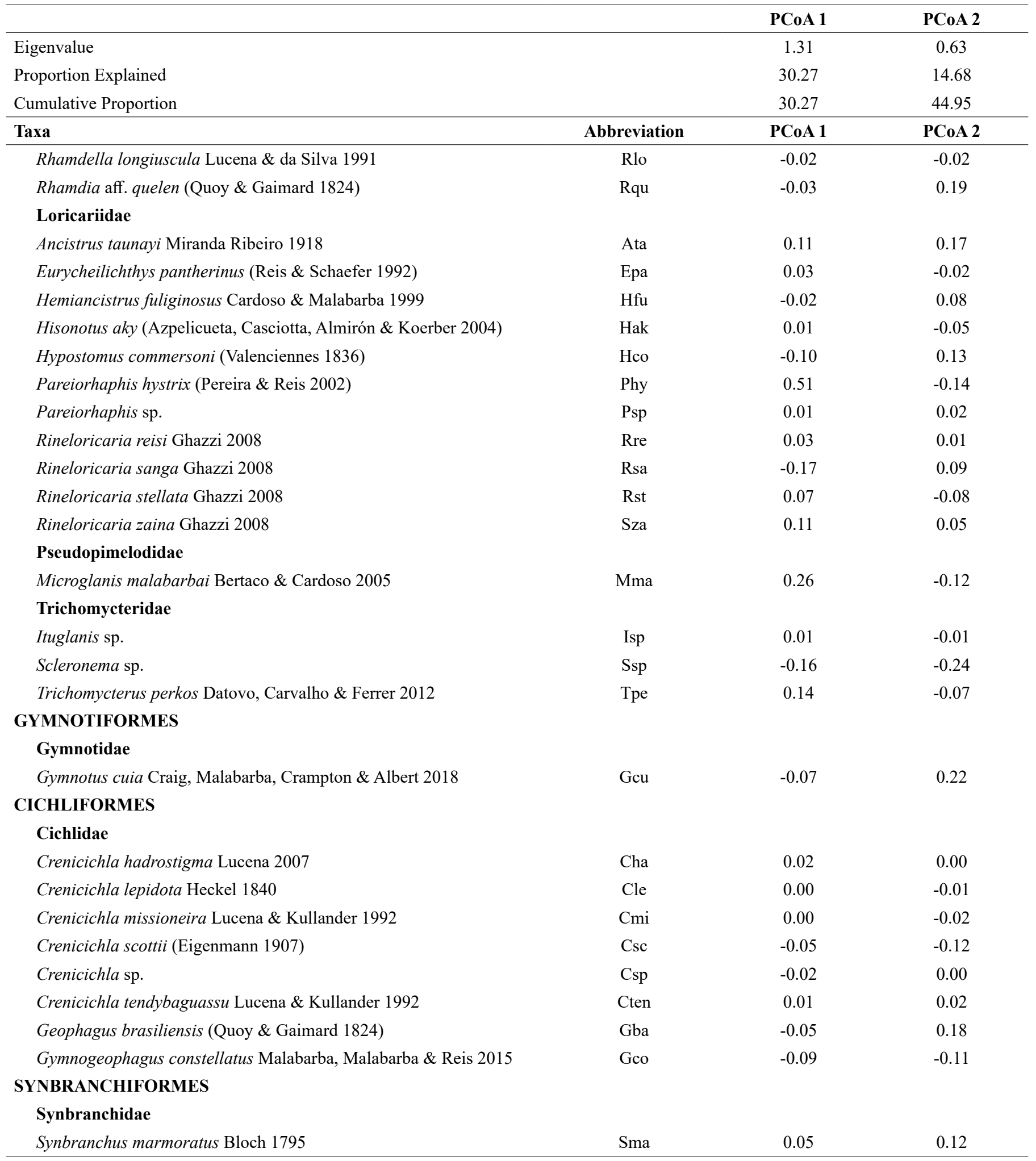


than species of headwaters are lost (Osborne \& Lewis, 1992). Therefore, a stream fish community structure changes over time and space, and more changes may occur between different parts of the same stream than between different streams in the same drainage basin, in some cases, such as changes on species richness or diversity of functional groups that change along a headwaters (upstream) toward the mouth (downstream) gradient (Vannote et al. 1980, Araújo-Lima et al. 1995).

Stream 1, upper portion of the sub-basin, presented more species than the streams in the mid portion (streams 3 and 4), becoming an exception to the pattern of longitudinal distribution found for the species richness. We believe this result has been influenced by the size of the stream (wider and with a greater water flow than the others) and by the proximity of the sampling site to the stream discharge into a larger river (about 200 meters), the Ijuí River, the main river of the sub-basin. In addition, information available in the literature indicates size, volume, flow speed and diversity of habitats, among others, as factors known to influence the pattern of ichthyofauna richness distribution (Winemiller 1983, Tejerina-Garro et al. 2005, Ibañez et al. 2009, Bailly et al. 2016). The characteristics of this stream could also be responsible for the association of Siluriformes to the upper portion of the Ijuí River sub-basin, in relation to the representativeness of the families Heptapteridae and Loricariidae.

Regarding the conservation status of the species, Crenicichla hadrostigma Lucena 2007, Microglanis malabarbai Bertaco \& Cardoso 2005 and Trichomycterus perkos Datovo, Carvalho \& Ferrer 2012 are included in the list of threatened species, officially recognized by the 51.797 act of September 8, 2014, state of Rio Grande do Sul, and classified as "near threatened" (category VI), according to the criteria defined by the International Union for Conservation of Nature (IUCN) (FZB 2014). The other species captured appear as "least concern" (FZB 2014), or there is no information about the status of conservation due to the species description be posterior to the act publishing. Another reason for the lack of information is the existence of possible new species, like Heptapterus sp1, Pareiorhaphis sp., Ituglanis sp. and Scleronema sp., identified only to the genre level (Buckup 1988, Malabarba et al. 2013, J. Ferrer 2017, oral communication, Universidade Federal do Rio Grande do Sul). Therefore, we understand that studies like this contribute to the knowledge of the biological diversity of the south of Brazil, bringing complementary information about richness and abundance of endemic, threatened or of large distribution, grounding future research that could contribute to the conservation of fish biodiversity in Neotropical streams.

\section{Acknowledgements}

The authors would like to thank: the colleagues of the Ichthyology $\mathrm{Lab}$ at the Universidade Federal do Rio Grande do Sul for helping and companionship in fieldwork; Júlia Giora, Juliano Ferrer, Priscilla C. Silva, Rafael Angrizani and Tiago P. Carvalho for helping with species identification. The first author thank a PHD scolarship from Coordenação de Aperfeiçoamento de Pessoal de Nível Superior (CAPES).

\section{Author Contributions}

Laísa W. Cavalheiro: Substantial contribution in the concept and design of the study;
Clarice B. Fialho: Substantial contribution in the concept and design of the study.

\section{Conflicts of interest}

The author declare that they have no conflict of interest related to the publication of this manuscript.

\section{References}

Agostinho, A.A., Miranda, L.E., Bini, L.M., Gomes, L.C., Thomaz, S.M. \& Suzuki, H.I. 1999. Patterns of colonization in neotropical reservoirs, and prognoses on aging. In Theoretical reservoir ecology and its applications (J.G. Tundisi \& M. Straskraba, eds). International Institute of Ecology, São Carlos, p.227-266.

Albert, J.S. \& Reis, R.E. 2011. Historical biogeography of neotropical freshwater fishes. University of California Press, Berkeley.

ANA - Agência Nacional de Águas. 2016. Região Hidrográfica do Uruguai. Brasília, DF. http://www2.ana.gov.br/Paginas/portais/bacias/uruguai.aspx (last access in 26/06/2016).

Anderson, M.J. 2001. A new method for non-parametric multivariate analysis of variance. Austral Ecol. 26(1):32-46. https://doi.org/10.1111 /j.1442-9993.2001.01070.pp.x (last access in 10/04/2019).

Anderson, M.J., Crist, T.O., Chase, J.M., Vellend, M., Inouye, B.D., Freestone, A.L., Sanders, N.J., Cornell, H.V., Comita, L.S., Davies, K.F., Harrison, S.P., Kraft, N.J.B., Stegen, J.C. \& Swenson, N.G. 2011. Navigating the multiple meanings of $\mathrm{b}$ diversity: a roadmap for the practicing ecologist. Ecology Letters 14(1):19-28. https://doi.org/10.1111/j.1461-0248.2010.01552.x (last access in 10/04/2019).

Araújo-Lima, C.A.R.M., Agostinho, A.A. \& Fabré, N.N. 1995. Trophic aspects of fish communities in Brazilian Rivers and Reservoirs. In Limnology in Brazil (J.G. Tundisi, C.E.M. Bicudo, \& T. Matsumura-Tundisi, eds). ABC/ SBL, Rio de Janeiro, p.105-136.

Bailly, D., Cassemiro, F.A.S., Winemiller, K.O., Diniz-Filho, J.A.F. \& Agostinho, A.A. 2016. Diversity gradients of Neotropical freshwater fish: evidence of multiple underlying factors in human-modified systems. J Biogeography. 43(8):1679-89. https://doi.org/10.1111/jbi.12749 (last access in 10/04/2019).

Bertaco, V.A., Ferrer, J., Carvalho, F.R \& Malabarba, L.R. 2016. Inventory of the freshwater fishes from a densely collected area in South America-a case study of the current knowledge of Neotropical fish diversity. Zootaxa 4138(3):401-440. http://dx.doi.org/10.11646/zootaxa.4138.3.1 (last access in $10 / 04 / 2019)$.

Betancur-R, R., Wiley, E.O., Arratia, G., Acero, A., Bailly, N., Miya, M., Lecointre, G. \& Ortí, G. 2017. Phylogenetic classification of bony fishes. BMC Evolutionary Biology. 17-162. https://doi.org/10.1186/s12862-0170958-3 (last access in 10/04/2019).

Bonato, K.O. \& Fialho, C.B. 2016. Fishes of Alto Jacuí sub-basin: a poorly studied sub-basin of northwestern Rio Grande do Sul, Brazil. Check List. 12(2):1-9. https://doi.org/10.15560/12.2.1867 (last access in 10/04/2019).

Borcard, D., Gillet, F. \& Legendre, P. 2011. Numerical ecology with R. Springer, New York.

Brown, J.H. 2014. Why are there so many species in the tropics? Journal of Biogeography. 41(1):8-22. https://doi.org/10.1111/jbi.12228 (last access in 10/04/2019).

Buckup, P.A. \& Hahn, L. 2000. Characidium vestigipinne: A New Species of Characidiinae (Teleostei, Characiformes) from Southern Brazil. Copeia. 2000(1):50-155. https://doi.org/10.1643/0045-8511(2000)2000[0150:CV ANSO]2.0.CO;2 (last access in 10/04/2019).

Buckup, P.A. 1988. The genus Heptapterus (Teleostei, Pimelodidae) in southern Brazil and Uruguay, with the description of a new species. Copeia. 1988(3):641-53. https://doi.org/10.2307/1445382 (last access in 10/04/2019).

Cappato, J. \& Yanosky, A. 2009. Uso sostenible de peces en la Cuenca del Plata. Evaluación subregional del estado de amenaza, Argentina y Paraguay. Unión Internacional para la Conservación de la Naturaleza y de los Recursos Naturales (UICN), Gland. 
Carvalho, T.P. \& Reis, R.E. 2009. Four new species of Hisonotus (Siluriformes: Loricariidae) from the upper rio Uruguay, southeastern South America, with a review of the genus in the rio Uruguay basin. Zootaxa. 2113:1-40.

Casciotta, J.R., Azpelicueta, M. \& Almirón, A.E. 2002. Bryconamericus uporas sp. n. (Characiformes, Characidae), a new species from the rio Uruguay basin, in Argentina. Rev. suisse zool. 109:155-65. https://doi.org/10.5962/ bhl.part.79584 (last access in 10/04/2019).

Di Persia, D.H. \& Neiff, J.J. 1986. The Uruguay River system. In The ecology of river systems (B.R. Davies \& K.F. Walker, eds). Dordrecht, Dr. W. Junk Publishers, p. 529-621.

Eschmeyer, W.N., Fricke, R. \& Van Der Laan, R. 2018. Catalog of fishes: genera, species, references. California Academy of Sciences, San Francisco https://www.calacademy.org/scientists/projects/eschmeyers-catalog-offishes (last access in 20/12/2018).

Esteves, K.E. \& Aranha, J.M.R. 1999. Ecologia trófica de peixes de riachos. In Ecologia de peixes de riachos (E.P. Caramaschi, R. Mazzoni \& P.R. PeresNeto, eds). PPGE-UFRJ, Série Oecologia Brasiliensis, Rio de Janeiro, p.157-182.

FEPAM - Fundação Estadual de Proteção Ambiental Henrique Luiz Roessler. 2016. U90 - IJUÍ. Porto Alegre. http://www.fepam.rs.gov.br/qualidade/ bacia_uru_ijui.asp (last access in 28/06/2016).

FZB - Fundação Zoobotânica do Rio Grande do Sul. 2014. Avaliação do Estado de Conservação de Espécies - Fauna - RS - 2014. Porto Alegre. https:// secweb.procergs.com.br/livlof/?id_modulo=1\&id_uf $=23 \&$ ano $=2012$ (last access in 28/06/2016).

Galves, W., Shibatta, O.A. \& Jerep, F.C. 2009. Estudos sobre a diversidade de peixes da bacia do alto rio Paraná: uma revisão histórica. Semina: Ciência Biológicas e da Saúde. 30(2):141-54. https://doi.org/10.5433/16790367.2009v30n2p141 (last access in 10/04/2019).

Ghazzi, M.S. 2008. Nove espécies novas do gênero Rineloricaria (Siluriformes, Loricariidae) do rio Uruguai, do sul do Brasil. Iheringia, Sér. Zool. 98(1):100-22. https://doi.org/10.1590/S0073-47212008000100014 (last access in 10/04/2019)

Ibañez, C., Belliard, J., Hughes, R.M., Irz, P., Kamdem-Toham, A., Lamouroux, N., Tedesco, P.A., Oberdorff, T. 2009. Convergence of temperate and tropical stream fish assemblages. Ecography. 32(4):658-70. https://doi. org/10.1111/j.1600-0587.2008.05591.x (last access in 10/04/2019).

Jenkins, J.A., Bart Jr, H.L., Bowker, J.D., Bowser, P.R., MacMillan, J.R., Nickum, J.G., Rachlin, J.W., Rose, J.D., Sorensen, P.W., Warkentine, B.E. \& Whitledge, G.W. 2014. Guidelines for Use of Fishes in Research-Revised and Expanded. Fisheries 39(9):415-16. https://doi.org/10.1080/03632415.2 014.924408 (last access in 10/04/2019).

Langeani, F., Castro, R.M.C., Oyakawa, O.T., Shibatta, A.O., Pavanelli, C.S. \& Casatti, L. 2007. Diversidade da ictiofauna do Alto Rio Paraná: composição atual e perspectivas futuras. Biota Neotrop. 7(3):181-97. https://doi. org/10.1590/S1676-06032007000300020 (last access in 10/04/2019).

Legendre, P. \& Legendre, L. 1998. Numerical ecology. Elsevier Science B. V., Amsterdam.

Lowe-McConnell, R.H. 1999. Estudos ecológicos de comunidades de peixes tropicais. EDUSP, São Paulo.

Lucena, C.A.S. 2007. Two new species of the genus Crenicichla Heckel, 1840 from the upper rio Uruguay drainage (Perciformes: Cichlidae). Neotrop Ichthyol. 5(4):449-56. https://doi.org/10.1590/S1679-62252007000400004 (last access in 10/04/2019).

Malabarba, L.R. \& Malabarba, M.C. 2014. Filogenia e classificação dos peixes neotropicais. In Biologia e Fisiologia de Peixes Neotropicais de Água Doce (B. Baldisserotto, J. Cyrino \& E. Urbinati, eds), FUNEP, Jaboticabal, p.1-12.

Malabarba, L.R., Fialho, C.B., Anza, J.A., Santos, J.F. \& Mendes, G.N. 2009 Peixes. In Biodiversidade dos Campos do Planalto das Araucárias (I.I. Boldrini, ed), Ministério do Meio Ambiente, Brasília, p.131-156.

Malabarba, L.R., Malabarba, M.C. \& Reis, R.E. 2015. Descriptions of five new species of the Neotropical cichlid genus Gymnogeophagus Miranda Ribeiro, 1918 (Teleostei: Cichliformes) from the rio Uruguay drainage. Neotrop Ichthyol. 13(4):637-62. https://doi.org/10.1590/1982-0224-20140188 (last access in 10/04/2019).
Malabarba, L.R., Neto, P.C., Bertaco, V.A., Carvalho, T.P., Ferrer, J. \& Artioli, L.G.S. 2013. Guia de identificação dos peixes da bacia do rio Tramandaí. Via Sapiens, Porto Alegre.

Meyer, J.L., Strayer, D.L., Wallace, J.B., Eggert, S.L., Helfman, G.S. \& Leonard, N.E. 2007. The contribution of headwater streams to biodiversity in river networks. Journal of the American Water Resources Association. 43(1):86103. https://doi.org/10.1111/j.1752-1688.2007.00008.x (last access in 10/04/2019).

Moore, J.A., Lew, A., Cunningham, J.A. \& Kachuba, M. 1997. Fish communities as indicators of environmental quality in the West River watershed. Bulletin of the Yale School of Forestry and Environmental Studies. 100:178-96.

Oksanen, J., Blanchet, F.G., Friendly, M., Kindt, R., Legendre, P., McGlinn, D., Minchin, P.R., O’Hara, R.B., Simpson, G.L., Solymos, P., Stevens, M.H.H., Szoecs, E. \& Wagner, H. 2017. Vegan: Community Ecology Package. R package version 2.4-5. https://CRAN.R-project.org/package=vegan (last access in 10/11/2018).

Osborne, L.L. \& Wiley, M.J. 1992. Influence of tributary spatial position on the structure of warmwater fish communities. Canadian Journal of Fisheries and Aquatic Sciences. 49(4):671-81. https://doi.org/10.1139/f92-076 (last access in 10/04/2019).

Pereira, A.L., Ribeiro, V.R., Gubiani, E.A., Zacarkim, C.E. \& Cunico, A.M. 2014. Ichthyofauna of urban streams in the western region of Paraná State, Brazil. Check List. 10(3):550-555. https://doi.org/10.15560/10.3.550 (last access in 10/04/2019).

Reis, R.E. 2013. Conserving the freshwater fishes of South America. Int Zoo Yearb. 2013. 47(1):65-70. https://doi.org/10.1111/izy.12000 (last access in $10 / 04 / 2019)$.

Rose, P.M., Kennard, M.J., Moffatt, D.B., Sheldon, F. \& Butler, G.L. 2016. Testing three species distribution modelling strategies to define fish assemblage reference conditions for stream bioassessment and related applications. Plos One. 11:e0146728. https://doi.org/10.1371/journal. pone.0146728 (last access in 10/04/2019).

Schaefer, S.A. 1998. Conflict and resolution: impact of new taxa on phylogenetic studies of the Neotropical cascudinhos (Siluroidei: Loricariidae). In Phylogeny and classification of Neotropical fishes (L.R. Malabarba, R.E. Reis, R.P. Vari, Z.M.S. Lucena \& C.A.S. Lucena, eds), EDIPUCRS, Porto Alegre, p.375-400.

Tejerina-Garro, F.L., Maldonado, M., Ibañez, C., Pont, D., Roset, N. \& Oberdorff, T. 2005. Effects of Natural and Anthropogenic Environmental Changes on Riverine Fish Assemblages: a Framework for Ecological Assessment of Rivers. Braz Arch Biol Technol. 48(1):91-108. https://doi.org/10.1590/ S1516-89132005000100013 (last access in 10/04/2019).

Uieda, V.S. \& Castro, R.M.C. Coleta e fixação de peixes de riachos. In Ecologia de peixes de riachos (E.P. Caramaschi, R. Mazzoni \& P.R. Peres-Neto, eds). PPGE-UFRJ, Série Oecologia Brasiliensis, Rio de Janeiro, p. 01-22.

Vannote, R.L., Minshall, G.W., Cummings, K.W., Sedell, J.R. \& Cushing, C.E. 1980. The River Continuum Concept. Can J Fish Aquat Sci 37(1):130-37. https://doi.org/10.1139/f80-017 (last access in 10/04/2019).

Vari, R.P. \& Malabarba, L.R. 1998. Neotropical ichthyology: an overview. In Phylogeny and classification of Neotropical fishes (L.R. Malabarba, R.E. Reis, R.P. Vari, Z.M.S. Lucena \& C.A.S. Lucena, eds), EDIPUCRS, Porto Alegre, p.1-12.

Vidotto-Magnoni, A.P., Garcia, D.A.Z., Costa, A.D.A., Souza, J.G., Yabu, M.H.S., Almeida, F.S. \& Orsi, M.L. 2015. Ichthyofauna of streams of the Lower Paranapanema River basin, state of Paraná, Brazil. Check List 11(5):1-8. https://doi.org/10.15560/11.5.1756 (last access in 10/04/2019).

Winemiller, K.O. 1983. An introduction to the freshwater fish communities of Corcovado National Park, Costa Rica. Brenesia. 21:47-66. 